\title{
HISTORY, SYSTEMS AND FUNCTIONS OF PLEADING.*
}

\section{What Is Pleading?}

Before any dispute can be adjusted or decided it is necessary to ascertain the actual points at issue between the disputants. Conceivably this may be done in several ways. Perhaps the simplest is a process of direct questioning of the parties by the arbitrator or judge. Another method is the exchange of written statements in advance of a direct hearing of the parties. Under our Anglo-American system of legal procedure we are committed by tradition and history, by present practice and, probably, by general inclination, except in exceptional cases, to the latter inethod. ${ }^{1}$ Our system calls for the development of issues by the parties themselves in formal manner in advance of the actual trial. This is accomplished by requiring the serving on the opposing party or the filing in court alternately by the parties of pleadings - written instruments wherein are set forth the statements and contentions of each as to the points and facts in dispute. These pleadings are to be distinguished from the lawyer's oral argument or "plea" made to the court or jury at the trial of the case." Originally under the common law system

*This article will appear as the first chapter of a forthcoming book on Code Pleading and is here published through the courtesy of the West Publishing Co.

${ }^{1}$ Gibson, The Philosophy of Pleading, 2 Yale L. J. 181, citing Story, EQuity Pleading, $\& 1$; Stephen, Pleading, *1, *135-*136, *491-*494; Lloyd, Plcading, 71 U. of Pa. L. R. 26. For an extreme statement see Hughes, 44 Chicago Legal News 125, 134; for criticism of this point of view, see Roscoe Pound, 36 A. B. A. Rep. 480-482 (1911), also references in notes 12, 13, infra.

2 In Philitips, Code Pleadrang, $\$ 11$, there are collected various definitions of pleadings, including the famous one of Blackstone-"the mutual altercations between the plaintiff and the defendant." 2 BLAck, Comm. *283. See Ark. Dig. 1921, § 1183; "The pleadings are the written statements, by the parties, of the facts constituting their respective claims and defenses." Cal. C. C. P. $1923, \S 420$ : "the formal allegations by the parties of their respective claims and defenses, for the judgment of the court." See also Colo. Code 1921, § 52; Idaho Comp. Stat. 1919, § 6683; Ind. Burns Ann. Stat. 1914, $\S 340$; Iowa Comp. Code, 1919, § 7190; Kan. Rev. Stat. 1923, 60-701; Ky., 
the pleadings were oral, but for several centuries thiey have been written and have become technical legal documents, carefully framed by the attorneys of the parties. ${ }^{3}$ The content of these documents and the manner in which they are to be employed in the litigation have become the subject of rules in general of a highly refined nature. Pleading is the name given to the legal science which deals with these rules.

The pleadings therefore serve the primary purpose of acquainting the court and the parties with the facts in dispute. They shoukd in so doing point out the actual issues to be setthed. ${ }^{4}$ Several other purposes may also be served by the pleadings. Thus a Committee of the American Bar Association classified the main purposes to be achieved by the pleadings as follows: (1) to serve as a formal basis for the judgment to be entered; (2) to separate issues of fact from questions of law; (3) to give the litigants the advantage of the plea of res adjudicata if again molested; (4) to notify the parties of the claims, defenses and cross-demands of their adversaries. ${ }^{5}$ As hereinafter pointed out in the discussion of "Functions of Pleading," the purpose especially emphasized has varied from time to time. Thus in common law pleading especial emphasis was placed upon the issue-formulating function of pleading; under the earlier code pleading like emphasis was placed upon stating the material, ultimate facts in the pleadings: while at the

Carroll's Code, 1919, § 87; Mont. Rev. Code, 1921, § 9125 ; Nev. R. L. 1912, $\S 8605$; N. M. Ann. St. 1915, § 4101 ; Okla. Comp. Stat. 1921, § 262; Utah, Comp. L. 1917, § 6562; Wy. Comp. St. 1920, § 5647; P. R. Rev. Stat. 1911, $\S 5083$.

${ }^{3}$ On the change from oral to written pleadings during the fifteenth and sixteenth centuries, see Holdsworte, Hist. ENG. LAw (3rd Ed.), 639-656; 2 Seifer Essays in Anglo-American Legal History, 614. That a judgment rendered on oral pleadings may still be valid, see Rood, 10 Mich. L. R. 384.

- Campbell v. Walker, 1 Boyce (Del.) 580, 76 Atl. 475; Quaker Metal Co. v. Standard Tank Car Co. (Del.), 123 Atl. 131; Smith v. Jacksonville Oil Mill Co., 21 Ga. App. 679, 94 S. E. 900; Shipman, Common Law Pleading (3rd Ed. by Ballantine), 8-11; Isaacs, 16 Mich. L. R. 589.

35 A. B. A. Rep. 614, 638, 639 (1910), (prepared by Dean Roscoe Pound and approved by the committee) ; urging that the first function be abandoned, and that the notice function be emphasized. $C f$. Shipman, op. cit., 9, 10, on other suggested functions of pleading. 
present time the emphasis seems to have shifted to the notice function of pleading. ${ }^{6}$

It will be observed that pleading is therefore a branch of the law of remedies existing for the enforcement of the substantive jural relations of the parties. The difference between adjective or procedural law and substaniize law may easily be over-emphasized since the line between them is shadowy at best. It is, however, desirable that the purely secondary character of procedural rules should be borne in mind throughout the consideration of the subject. These rules exist not to be vindicated for themselves alone but merely to aid in the efficient application of the substantive law.

The system of pleading developed in the English courts of common law after the Norman Conquest and applied in legal actions in this country until the pleading reforms of the middle and the latter part of the nineteenth century is commonly called common law pleading. The system of pleading developed in the English courts of chancery and likewise applied in the equity courts in this country is termed equity pleading. Code pleading is the term applied to the reformed system of pleading initiated by the New York Code of 1848 and now in force in some thirty American jurisdictions. It is this latter system which concerns us in this book. But since it developed from the former systems and in many respects continues various details and parts of them, it is necessary to consider the antecedents of code pleading in the other systems. This is done briefly and in broad outline only.

All the pleading herein referred to is civil pleading or pleading in civil attions, as distinguished from criminal procedure, dealing with criminal actions, or actions by the state for the punishment of crimes. There is a certain amount of pleading in criminal proceedings, and this bears some general similarity to pleading in civil actions; but the distinctions are important. and make separate treatment of that subject desirable. ${ }^{\top}$

Roman Civil Procendure.

It is usual to consider the listory of civil procedure in ancient Rome as dividing into three periods. The first, that of the

\footnotetext{
${ }^{\circ}$ Infra, p. 543.
}

Tee texts on criminal procedure, c. g., that by W. L. Clark. 
legis actio procedure, lasted through the early days of the Republic; the second, the period of the formulary procedure, covered the later days of the Republic and the early days of the Empire; and the third, that of the libellary procedure, comprised the latter days of the Empire. ${ }^{8}$

\section{The Legis Actio Procedure.}

The first period, as is usual in the history of procedure, was a period of extreme formalism. There were five forms of the legis actio, within the terms of one of which the plaintiff must compress his claim if he would secure judicial relief. The analogy to the forms of action under the English common law system of pleading - hereinafter referred to - is striking, though a direct connection between the two is denied. ${ }^{9}$ There is also another analogy between the two systems, for in each the issue is formulated in advance of the actual trial and such trial is had before those who have had nothing to do with forming the issue. At this stage of the Roman procedure, however, the issues were fixed and formal, arrived at before the magistrate (normally, the pretor) by repeating certain traditional terms. The magistrate, if the issue was properly made, then granted the right to proceed to trial. The actual trial was before a iudex, who was not a public officer, but a private person from a specially selected class. ${ }^{10}$ Under the common law the jury which tries the case likewise receives it with the issue already actually framed, but by the parties in their pleadings rather than by a public magistrate.

\section{The Formulary Procedure.}

The immutable oral formulæ of the legis actio became inadequate for the growing law. The necessary means of expan-

${ }^{8}$ Sof M, Institutes (trans. by Ledlie, 3rd Ed.), 224-301; BuckLANd, TextBook of Roman Law, 599-667; Kocourek, The Formula Procedure of Roman Laze, 8 VA. LAw REv. 337-355, 434-444.

- That the English formulary system is not of Roman origin, see 2 PoiLOCK \& Marruand, Hrst. ENG. LAw (2nd Ed.), 557-9. For a contrary view, see John Randolph Tucker (1892), Va. State Bar Ass'n Rep. 85, 89. Cf. STEPhen, Pleading, notes 6, 7. Apparently the modern tendency is to look for a greater influence on English law by the Roman law than had previously been thought to exist. $C f$. G. E. Woodbine, 33 Yale L. J. 812, 813; 31 ibid. 827.

${ }^{10}$ For the selection of itdices, see Buckland, op. cit. 631. 
sion were found outside this procedure. The legis actio was available only as between Roman citizens. But by 242 B. C. a special pretor had been appointed to deal with actions where one or both of the parties were aliens. In shaping his procedure the pretor naturally was guided by the practice which obtained as between citizens, and hence we find him formulating the issue and referring the decision of the issue to one or more private individuals, just as in the legis actio procedure. But with foreigners there was no lex governing as in the case of the legis actio, and hence the pretor drew up the issue to fit the case and this issue was then given by the plaintiff to the defendant and accepted by him.

Thus in the legis actio the issue was arrived at by means of an oral formula based on a popular statute and rigorously confined to a limited number of claims. In the formulary procedure it was made by means of a written formula capable of being adapted to the greatest variety of claims, drawn up by the magistrate and accepted by the parties. The latter naturally became the more popular; and by act of the prator urbanus, followed by legislative enactment, it was made available to Roman citizens. This resulted in the triumph of the formulary procedure over the older form. ${ }^{11}$

The infuence of the formula thus permitted upon the development of both procedural and substantive law was very great. The pretor by his power over the formulation of the issue was able to and did reform and remake the substantive law. From the pleading standpoint the procedure is most interesting. We still have the issue-making stage of the trial, but the issue is made by a court officer and not by the parties themselves who are either ill-trained or are anxious to avoid disclosing any more of their case than they can help. The Roman system has been highly, almost extravagantly recommended by a modern writer as avoiding the chief defect of our own system of justice. ${ }^{12}$ It

"See citations, note 8 , supra.

${ }^{22}$ Kocourek, 8 VA. LAw REv. 337, 338: "This method of administering justice was the most remarkable and the most successful that has ever been carried out on a large scale over an extended period in any civilized country"; "the chief defect of our own administration of civil justice * * * we think rests on this proposition; a disputed matter of fact or law or of 
has somewhat of an analogy under the present English system where causes are referred to masters in chancery for the framing of issues. ${ }^{13}$

\section{Tht Later Libellary Procedure.}

Under the Empire the imperial power limited the power of the pretor, and took to itself the function of developing the law. The prator as well as the iudex became simply a ministerial offcer for carrying out the law, and the new procedure then developing followed the form of proceedings before the emperor. The two stages of the trial were abandoned and the entire proceeding was before a magistrate whose function it was to apply the law. By the middle of the fourth century the process of applying for a formula was given up, the parties submitting their claims to the magistrate without the formal making of an issue and with only a short statement, or libellus of the ground of suit. ${ }^{14}$ It is this system which was followed on the continent, where the Roman law was the basis of the later jurisprudence of. the country, and it is this system in effect which is now in vogue in the continental countries. It also made its impress on ecclesiastical law and so to a certain extent on the equity prac-

both, cannot be resolved into simple, ultimate questions of the merits of a controversy by any system of procedure which leaves the formulation of these issues to the adversaries themselves." See also Kocourek, 5 Journ. Am. Jud. Soc. 101.

${ }^{13}$ For description of the English practice, see Leaming, A Philadelphia Lawyer in the London Courts, Chap. 10, 5 Mass. L. Q. 250-253; Higgins, 7 Journ. Am. Jud. Soc. 204-206; Order 30, r. 1-8, Rules under Judicature Act, Annual Practice, 1924, 471-483 ("Summons for Directions"). A similar practice has been developed in New Jersey, Prac. Act, 1912, § 17; Rules of Supreme Court (1919), Rules 61-65; Second Report of Jud. Comm. Mass. 1921, 110-113; cf. ibid. 107: "A century ago Jeremy Bentham made a suggestive classification of methods of procedure into 'epistolary' methods and 'confrontatory' methods, and he made caustic remarks about the epistolary kind. The comparison may be simply translated into the statement that one can generally find out more quickly about facts by talking directly to a man who knows about them than by conducting a long and cautious correspondence with him or with somebody representing him. This simple idea has been very gradually forcing its way into legislation and rules of court relative to procedure." See Report of Board of Statutory Consolidation (N. Y. 1915), 21, 205-207, note 29 , infra.

14 See note 8, supra. Engelmann, Der Romische Civit,prozess, 84. The formulary procedure was finally abrogated. Ibid., 80 . 
tice in England. ${ }^{15}$ It therefore has probably had a more direct effect upon our modern systems than either of the earlier Roman systems.

\section{Modern Continental, Civil, Proceidure.}

Like the later Roman procedure, which formed a part of the civil law, the basis of continental jurisprudence, modern continental civil procedure places little emphasis upon written pleadings prior to the trial. The absence of the system of jury trials renders less important the definite and clear formulation of an issue in advance of trial. A considerable divergence in principle is apparent between the continental and the AngloSaxon systems. Continental jurists have devoted much attention to procedural jurisprudence, whereas our writers on procedure have tended to limit themselves simply to the practical details of their own systems. The researches of modern scholars, especially of Professor R. W. Millar, are now making the continental literature more available to us, and should lead to a greater development of this aspect of the subject. ${ }^{16}$ Perhaps the most important divergence so far as concerns our subject of pleading is that under the continental system the principle termed that of "orality," (oral allegations) is followed, while under our own since an early time the principle of documentation, or written pleadings, is followed. True the continental systems provide for certain written statements of the parties. In general the plaintiff is required to state the nature and grounds of his demand in connection with or in the summons, and in some systems, such as the German, he must set forth the names of the

${ }^{25}$ Langdei., Equity Pleading (2nd Ed.), 1-6, 17-19, 42, 43; 2 Select Essays in ANglo-Amerrcan History, 753-778. Cf. Engelmann, op. cit., 84, that the form given the libellary procedure by Justinian is of great importance, "for it became the basis for the further development of the law of procedure and resembles in essential points the law of procedure appearing in Germany to-day."

${ }^{16}$ Professor Millar is editing a volume for the Continental Legal History Series to be entitled The History of Contrnental Civiz Procedure which will contain a translation of ENGELMANN, DER CrvilpRozess, and other Continental materials. See also Millar, The Formative Principles of Civil Procedure, 18 Ill. Law Rev. 1, 94, 150, reprinted in pamphlet form. 
witnesses and the evidence they will give. ${ }^{17}$ Provision is usually made for a written answer by the defendant and a written reply by the plaintiff, but these ordinarily are optional with the parties. The real pleadings are the oral conclusions alleged in open court at the hearing of the case. These may be required to be put in writing later, but this is simply for purposes of record. ${ }^{18}$ Under such a system it is obvious that comparatively little importance is attached to the preceding informatory statements of the parties. This explains the comparative absence of decisions on questions of pleading on the continent. ${ }^{19}$

A comparison of the two systems with respect to certain other procedural principles will further illustrate the point. Under both all the parties to the case must be given an opportunity to be heard (the principle of bilaterality of the hearing) and the case is presented by them, party presentation as distinguished from judicial investigation. But under the conmon law the parties, and not the judge, control the advance and prosecution of the suit ( $i$.e., party prosecution) while in European countries the judge has much more to do with seeing to the ultimate disposition of the case (the principle of judicial prosecution applied at least to a modified extent). It is significant that modern English procedure tends to put much greater responsibility upon the judge in the prosecution of the suit. Even more striking is another difference. In common law procedure, the two main stages of the suit - pleading and trial - were made entirely distinct and if a party did not act at the appointed stage, he lost his opportunity and was later precluded from doing what otherwise he might have done. (This is termed the principle of stage-preclusion.) On the other hand the continental countries tend towards almost complete procedural freedom. This latter

${ }^{17}$ Millar, The Formative, Principles of Civir, Procedure, 47-59. $C f$. K. von Lewenski, Courts \& Procedure in Germany, 5 Ill. Law Rev. 193; S. E. Baldwin, A German Laze Suit, 19 Yale L. J. 69; 8 Mich. L. R. 30 . See also Millar, The Recent Reforms in German Civil Procedure, 10 A. B. A. Journ. 703-9.

18 The statements in the text apply especially to France and Germany, and to the more usual procedure in Italy. In Spain the allegations are written. See Millar, op. cit. 49-56.

${ }^{10}$ E. M. Borchard, Some Lessons from the Civil Lave, 64 U. of Pa. L. R. 570, 578. Cf. S. S. Clark, 14 Yale I. J. 263. 
is of course the modern tendency in both England and America, still somewhat restricted by the existence of, jury trials. But the whole trend of the continental systems is to treat the ascertainment of the issues as part of the trial itself. The result is naturally to lessen the importance of pleading. ${ }^{20}$

A comparative estimate of the two systems from the standpoints of efficiency and of accomplishment is highly desirable. On the surface it is apparent that the continental system has the great advantage over our own of avoiding in the main all the extensive litigation over pleading and procedural points which is such a reproach to our system of justice. On the other hand there should be a considerable advantage in having the issues disclosed before trial. With the differences so made clear, the chances of the parties themselves settling their disputes should be increased, and the actual trial should be much shortened and simplified.21 An inquiry into the comparative merits of the systems involving perhaps such questions as the length of litigation, the length of the actual trials, the cases settled without hearing, the expense, the current criticism of the courts or lack thereof, and so on, might well be undertaken by one of the bodies interested in the advancement of legal science. For the present we may note a general tendency in our law, somwhat comparable to the development of Roman civil procedure, toward the continental practice of not stressing the pleading stage of the trial. So long, however, as we have the jury system of trial, with its natural emphasis upon the previous formulation of the issues, it is unlikely that we shall come fully and completely to the continental practice.

\section{Common Law Pieading.}

The common law system of pleading came into vogue in England after the Norman Conquest. It developed as a more or less gradual process; the beginnings of most of the common law actions cannot be stated with absolute precision. ${ }^{22}$ By the time of Edward I it had become a science to be formulated and culti-

\footnotetext{
so Millar, op. cit. 4-47.

21 Stephen, Pleading, *491-*499; note 1, supra; notes 24, 27, infra.

${ }^{2}$ Woodbine, The Origins of the Actions of Trespass, 33 Yale L. J. 799; 34 ibid. 343. Cf. Ames, Lectures in Legal History, 47, et seq. (the lectures on the various forms of action).
} 
vated. ${ }^{23}$ From that time until the time of the reforms of the nineteenth century the "science of special pleading" was of the utmost importance and among its devotees are included the great legal names of all but the most recent English law. ${ }^{24}$

Since the facts were passed upon by a body of laymen, not by a trained judge, it was felt necessary to ascertain clearly the points of dispute between the parties before the trial was begun. The institution of trial by jury, which meant so much to our ancestors in their efforts to secure a free and impartial justice, is therefore responsible for this striking characteristic of common law pleading - the development of an issue. ${ }^{25}$ Unlike the Roman formulary system the issue was to be made by the parties themselves, not by a judicial officer of the government. Hience under the original idea of common law pleading each party must in turn answer the previous pleading of his adversary by either denying, or affirming and adding new matter (confessing and avoiding) until there is ultimately reached a stage where one side has affirmed and the other has denied a single material point in the case. This was the issue, and except as modified by later rules, provision was made for only one such issue. ${ }^{26} \mathrm{It}$ was thought to be the glory of the system that the parties themselves would thus in advance of the trial single out and disclose the one material point as to which they were in dispute, thus eliminating all extraneous or agreed matter. The highly technical rules so characteristic of the system of common law pleading were in the main designed either to aid or to force the parties in this manner to formulate the issue. ${ }^{27}$

2 Stephen, Pleading, *135.

2* Special pleading refers to pleading by specific as opposed to general allegations. Hepburn, The Development of Code Pleading, 65, 66; StePHEN, Pleadrng, *169, note (a). "Special pleading contains the quintessence of the law, and no man ever mastered it, who was not by that means made a profound lawyer." Story, J., quoted in Shrpman, Comron Law PleAdring (3rd Ed. by Ballantine), 4.

${ }^{25}$ Holsworth, op. cit., note 3, supra.

${ }^{20}$ Stephen, Pleading (Williston's Ed.), *136-*149, *491-*499.

27 Among the many ecomiums on the system may be cited that of Stephen, op. cit. note 26, supra; of Mr. Justice Grier, McFaul v. Ramsey, 20 How. 525, 15 L. Ed. 1010, and of ANDrews, AMERICAN LAw (2nd Ed.), § 635. See also 10 Harv. L. R. 238, 239. For other references, see Shipman, op. cit. 4, 5; Ballantine, 1 Ill. L. Bull. 1. 
The other great characteristic feature of common law pleading - the forms of action - has a close connection with the triumph of the king's courts over the local courts, a history too long to be traced in detail here. ${ }^{28}$ Whenever a litigant desired to sue in the king's court, he was required to procure a writ from the king through the office of the chancellor, that is, from the clerks in chancery. The writ was the king's command directing the sheriff to summon the defendant before one of the king's courts. It served the further important purpose of giving jurisdiction to the court named in it. ${ }^{29}$ The process of issuing writs came to be strictly limited to cases where precedents existed, so that a litigant had to bring his claim within the limits set by some former precedent. Many writs were developed in reference to land but because of the cumbersome nature of the procedure gradually fell into disuse. Actions for money damages - called personal actions - were the actions in general use under this system of pleading. At its later development, due to the restrictions on the issuance of new writs, these were limited to the famous forms of action - trespass, trespass on the case, trover, replevin and detinue in tort; and covenant, debt, account and assumpsit in contract. The action of ejectment came to be practically a substitute for all the actions concerning land. ${ }^{30}$

The practice of the clerks in chancery of forming new writs had ceased by the middle of the thirteenth century. By the Statute of Westminister, 1285, the clerks were directed that, where in a like case (consimili casu) falling under the same right and requiring a like remedy to one where a writ was found, there was no writ, they should frame one, or refer the case to Parliament for the making of one. This was designed to add some flexibility to a system which had already become rigid. According

* Adams, The Origin of the English Courts of Common Law, 30 Yale L. J. 798-813, and authorities there cited; AdAMS, ORIGIN OF THE LiNGIISH Constitution (Ed. 1920), Chap. III and note; $c f$. Perru, Comaron Law Pleading, 28-37; Maitldand, Equity and The Forms of Action, 295, et seq.

$\approx$ Hence the name given it of original or originating writ. See STEPHEN, Pleadming, *5-*8, *II-*VII; Shipman, op. cit. 57-61. Cf. Maitland, History of the Register of Original Writs, 3 Harv. L. R. 97, 169; 2 Select Essays in ANglo-American Legal. History, 549.

${ }^{\text {so }}$ See authorities referred to in note 29, supra; Shipman, op. cit. 62-65. 
to the current belief (which, perhaps, is not accurate), it did lead to the formation of the writ and the consequent development of the action of trespass on the case, from which trover and assumpsit later developed. But it did not bring about a general issuance of new writs. Hence the common law system was limited in the extent of the relief which it could grant and the manner of granting it to the arbitrary units comprising the forms of action. Coupled with this were the refinements enforced to induce the production of an issue, resulting in a higlily technical system which afforded none too complete relief. ${ }^{31}$ The rise of the courts of equity served, however, to postpone the necessity of reform for some time.

\section{Equity Pleading.}

The equity courts developed from the exercise by the king of his royal prerogative through his Chancellor to do justice where the courts failed to do so. Since the first Chancellors were churchmen, they followed the ecclesiastical law. In this way equity pleading goes back through the canon law to the later period of the Roman law, although the connection is not so direct as to have been completely controlling. ${ }^{32}$ But we do find a general similarity between the English equity system and the Roman libellary procedure in the absence of a separate body for the trial of facts and hence the absence of emphasis upon the formation of an issue. Likewise there were no forms of action in equity; the complainant stated his case at large in the form of a petition to the Chancellor. The pleadings in equity were, however, quite detailed, since, being sworn to, they gave the facts upon which the case was decided. No formal trial with witnesses was ordinarily had, at least until modern times. The equity procedure was much more flexible in many respects, particularly as

${ }^{31}$ Hepburn, The Development of Code Pleading, Chap. II; 2 Select EsSays, 643; Ongers, A Century of Law Reforar, 203; Lord Bowen, 1 Seifect Essays, 516. The reseatches of my colleague, Professor George E. Woodbine (not yet published) throw doubt upon the traditional view of the origin of trespass on the case.

52 IANGDELI, EQUity Pleading, note 15, supra; KaigwiN, Cases in EQuity Pleading (1924), 10-19; cf. Adams, Origin of Englisi Equity, $16 \mathrm{Col}$. L. R. 86; Kittle, 21 W. Va. L. Q. 21 ; MAITlaNd, EQUITY AND THE Forms of Action, 1 ff. 
to joinder of parties and of actions, and as to the form and kind of judgment which might be rendered. ${ }^{33}$

The later reform of pleading by the codes owed much to equity pleading. When it was proposed to combine the common law and equity systems into a single blended system, it was to equity that the codifiers went for most of their modifications of the common law. This appears in such matters as the statement of facts, which in principle followed the equity procedure though without the same detail, the joinder of parties, which was taken directly from equity, and the split judgments of the code. ${ }^{34}$ The equity procedure itself was designed as a flexible system to meet varying claims and hence was of a kind to appeal to those who were attempting to change the harshness and inflexibility of the common law. But equity jurisprudence too had tended to become rigid; the procedure seems to have aggravated the delays apparently natural to all systems of law, and hence it also came to the point where it was not fulfilling the needs of a growing and developing system of law. The division of the remedial justice into two systems with two courts entirely distinct from each other intensified the defects inherent in each system. A litigant not infrequently would have to be sent out of court to bring his action in another tribunal simply because he had chosen the wrong one. Since the rules governing the clioice of tribunal were not always clear and easy of application, the harm to innocent seekers for justice was great. ${ }^{35}$

\section{THE REFORM OF PLEADING.}

In 1765 William Blackstone published his tamous Commentaries on the Law of England in which he apotheosized the then existing law of his country. Not the least interesting and im-

${ }^{23}$ Ibid. The substitution of testimony taken in open court for that by deposition was made in the Federal equity courts only by the rules of 1912 (Rule 46). See 36 A. B. A. Rep. 456-459. 48 ibid. 326. Cf. Dickinson v. Todd, 172 Mass. 183, 51 N. E. 976, Cook's CAs. E. 186.

* See First Report of the Commissioners on Practice and Pleadings (N. Y. 1848), 124, 145, 141, 142, 147; Clark, The Code Cantse of Action, 33 Yale L. J. 817.

is A. Birrell in A Century of Law Reform, 176-202; W. B. Odgers, ibid. 203-240; First Report of N. Y. Commissioners (supra, note 34), 67-88, 137147 ; Lord Bowen, 1 Select Essays, 516. 
portant outcome of that epoch-making work, - one not expected and hardly to be appreciated by that great exponent and defender of things as they were - was in the reaction to it of a young pupil of. Blackstone, Jeremy Bentham, who heard the lectures later published as the Comnientaries and was affected by the system there described in quite the opposite way from the lecturer himself."36 Benthan then and there began his long continued attack on abuses in the administration of justice. His work continued for half a century and very slowly he and his followers set in motion a movement for law reform which had the most important results in both England and America. ${ }^{37}$

In England beginning in 1828 Parliament appointed a series of commissions to examine the law of procedure and other subjects and to report changes to be enacted. The first tangible reform was the "Hilary Rules," the "New Rules" of 1834, passed at Hilary term and framed by the judges in pursuance of the statute of $3 \& 4 \mathrm{Wm}$. IV, c. 24 . The especial accomplishment of these rules was to limit the scope of the general issue in the formed actions and to force the defendant to set up affirmatively all matters other than a denial of the breach of duty or wrongful act of the defendant. ${ }^{38}$

In 1848 came the first of the American reforms of pleading with the adoption of the New York Code. Undoubtedly this further stimulated the reform movement in England. ${ }^{39}$.The next step was the Common Law Procedure Act, passed by Parliament in 1852, followed by a series of statutes reforming the

${ }^{30}$ His first book, FRAGMENT on GoverNMENT (1776), was a direct attack upon Brackstone's Commentaries. See the preface thereto (Ed. Montague), 94.

3 Hepburn, The Development of Cone Pleading, 71-74; 1 Dirlon, Laws and Jurisprudence, 316; Dillon, 1 Select Essays, 492, quoting Sir Henry Maine: "I do not know a single law reform effected since Bentham's day which cannot be traced to his influence."

ss STEPhen, Pleading (Williston's Ed.), *173-*189. The use of several counts or pleas for the same cause or defense was also prohibited. Ibid., *LXXVII-*LXXXVI. See also Shipman, Common Law Preadrng (3rd Ed. by Ballantine), 312, 335 .

${ }^{30}$ S. E. Baldwin, Plcading in Civil Actions, Two Centuries Growth of Amerrcan Law, 313, 317; Hepburn, The Development of Code PleadING, 175. But see H. U. Sims, The Problem of Reforming Procedure, 21 Yale L. J. 215. 
system of pleading at law and another series reforming the pleadings in equity. These made important changes. Thus the Common Law Procedure Act provided for joinder of causes of action even though not of the same form of action, so breaking down the distinctions between the old forms of action. But these reforms were not drastic enough to suit the demand. In 1873 was passed the Supreme Court of Judicature Act which consolidated the great English courts at Westminister into one Supreme Court of Judicature and established a uniform law of procedure therefor. ${ }^{40}$ There was thus obtained the fusion of law and equity provided for earlier by the New York Code of Civil Procedure and the American codes. The procedure is in general similar to the American code pleading, but in many respects it has gone beyond the American system. It has furnished the model for some of the most advanced provisions in the most modern American practice acts. ${ }^{41}$ It is noteworthy in that the act itself does not regulate the details of practice but leaves these to the court, which makes and changes rules of practice. This has resulted in a highly flexible system, subject constantly to the revision and improvement which circumstances_and experience show to be necessary. It is one of the most generally commended features of the English procedure. ${ }^{42}$

The English reform influenced the Connecticut Code of 1879 , one of the most successful of the American codes, ${ }^{43}$ but until comparatively recent times it has not had the attention it deserves from American lawyers. The present tendency seems to be, however, to look to that system in the main for the changes now to be made in our pleading, so that a greater familiarity with

to $35 \& 36$ Vict., c. 66 ; for the act and its amendments, see The Annual Practice (1924), 2024-2154; for the history of the reform, see Birell, Odgers and Bowen, op. cit. note 35, supra; HEPBURN, THE DEVELOPMENT of CODE Pleading, Chap. VI.

"1 These provisions are referred to hereinafter. Examples may be found in the provisions for joinder of parties, for pleading in the alternative, and that in case of conflict between the rules of law and equity, the equity provisions shall prevail.

${ }^{2}$ Rosenbaum, The Rule Making Autlority of the English Courts (1917), originally published in Vols. 63-64 U. of $\mathrm{Pa}$. L. R., and in other reviews. See note 102, infra.

${ }^{43}$ S. E. Baldwin, op. cit. note 39, supra; also in 35 N. Y. State Bar Ass'n Rep. 829; Hepburn, The Development of Code Pleading, 112, 113. 
English rules and precedents may be demanded in the future of the American lawyer. Opinions differ as to the complete success of the English system. ${ }^{44}$ It must be admitted that, as the number of judicial rulings show, the English procedure is not entirely simplified. ${ }^{45}$ But many of the provisions seem well designed to secure practical convenience of trial and are worthy of emulation in our system, especially in their manner of expression which is not that of arbitrary nomenclature and definition so much as of direction for the guidance of the trial court. ${ }^{46}$

\section{The Rise of Code Pleading.}

\section{The New York Code of 1848 .}

In New York the movement for reform, which had been making some real strides in England, became especially strong just prior to the middle of the nineteenth century. By a new constitution, adopted in that state in 1846, the court of chancery was abolished, and there was created in its place a court having general jurisdiction in law and equity. Further, the next legislature was directed to provide for the appointment of three commissioners "to revise, reform, simplify and abridge" the practice and pleadings of courts of record of the state. ${ }^{47}$ The following year the legislature instructed the commissioners more explicitly,

4 For highly favorable views, see W. B. Perkins, 12 Mich. L. R. 277, 362; Lord Loreburn, 26 Harv. L. R. 98, 5 Mass. L. Q. 165; W. E. Higgins, 7 Jounr. Am. Jud. Soc. 185-234, and cf. current and past volumes of that journal. Compare W. H. Taft, 6 ibid. 43-46, 8 A. B. A. Journ. 605-607, 47 A. B. A. Rep. 263-266 (1922); Rosenbaum, op. cit. note 42, supra. For less favorable views, see H. U. Sims, 21 Yale L. J. 215; W. N. Gemmill, 4 Ill. L. R. 457; A. H. R, 75 Cent. L. J. 402. Cf. Hepburn, op. cit. Chap. VI; W. C. Loring, 8 A. B. A. Journ. 609-611; A. M. Kales, 4 I1l. L. R. 303, 5 ibid. 265. On the rule making power of the judges, see note 102, infra. For favorable comments on the system in Ontario, see W. R. Riddell, $62 \mathrm{U}$. of Pa. L. R. 17, 35 N. Y. St. Bar Ass'n Rep. 806; 6 Journ. Am. Jud. Soc. 6-17; 5 A. B. A. Journ. 639; Amram, 62 U. of Pa. L. R. 269; Harley, 12 Mich. L. R. 339, 447; 5 Journ. Am. Jud. Soc. 144.

15 See the bulky Annual Practice, the annotated rules of practice, published each year by Messrs. White and King (in 1924) containing pages cccciv, 2419; 400 (index). Cf. remarks of Bijur, J., in $137 \mathrm{E} .66$ St. $v$. Lawrence, 118 Misc. Rep. 486, 194 N. Y. S. 762, 769, 770.

${ }^{4}$ See reference to many of these hereinafter in this article under the title Future Reforms of Pleading.

${ }^{47}$ N. Y. Const. 1846, Art. 6, § 24. 
directing them "to provide for the abolition of the present forms of action and pleadings in cases at common law, for a uniform course of proceedings in all cases whether of legal or equitable cognizance, and for the abandonment of all Latin and other foreign tongues, so far as the same shall by them be deemed practicable, and of any form and proceeding not necessary to ascertain or preserve the rights of the parties." 48 The commission speedily went to its task and the following year reported a code which with some amendments was passed on April 12, 1848, and became operative on the following first of July. ${ }^{49}$ The code was in large measure the work of David Dudley Field, one of the commissioners, and is generally referred to as the "Field Code."50 Though so expeditiously prepared and enacted, it has served as the model of all succeeding codes in this country. ${ }^{51}$

Characteristics of the Code.

Probably the most important characteristics of the code were the one form of action and the system of pleading the facts. The first still remains as the crowning achievement of the codes, although in many respects the full benefit of the change has not been completely realized even at the present time. ${ }^{52}$ The forms of action were abolished, the separation of law and equity was done away with, and in its place the codifiers planned a blended system of law and equity with only a single form of action to be known as the civil action. ${ }^{53}$ As to the second characteristic, it was planned that the parties should in their pleading state the facts in simple and concise form. ${ }^{54}$ Instead of the issue pleading

${ }^{48}$ N. Y. Laws, 1847, Chap. 59, § 8.

N. Y. Laws, 1848, Chap. 379. See First Report of the Commissioners on Practice and Pleadings (1848).

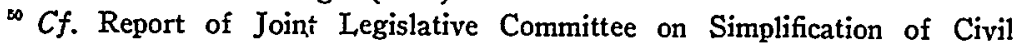
Practice (N. Y. 1919), 8-11; 35 N. Y. St. Bar Ass'n Rep. 829; HEPBURN, The Developanent of Code Pleading, 83.

"2 Hepburn, op. cit. 114, 124.

"2 See Clark, The Union of Lazu and Equity, 25 Col. L. Rev. 1 (1925). Professor Pomeroy rightly considered this the most fundamental part of the Code. Pomeroy, Code Remedies (4th Ed.), 5-7, XX-XXI (Preface to 1st Ed.).

First Report of the Commissioners on Practice and Pleadings (1848), 124, 145; ibid., Supplement, 3; Clark, The Code Cause of Action, 33 Yale L. J. 817 (1924).

Ibid., 75, 76, 141, 142, 147; Clark, op. cit. 33 Yale L. J. 821. 
of the common law there was to be fact pleading. As we shall have occasion to see later, this part of the plan has worked least successfully of all the reforms made, since the codifiers and the courts failed to appreciate that the difference between statements of fact and statements of law is almost entirely one of degree only. ${ }^{55}$

Among other important changes may be noted the adoption of the equity principles of greater freedom of joining parties and of rendering judgments in part for or against the various parties as the justice of the case may require (the split judgment of equity)..$^{56}$

\section{Spread and Modern Extent of Code Pleading.}

The system inaugurated by the New York Code of 1848 was adopted in Missouri in 1849, in California in 1850, in Kentucky, Iowa and Minnesota in 1851, and in a total of what are now twenty-four states within twenty-five years of its original enactment. ${ }^{57}$ The following may be considered the code jurisdictions at the present time: Alaska, (1900); Arizona, (1864); Arkansas, (1868); California, (1850); Colorado, (1877) ; Connecticut, (1879); Indiana, (1852); Iowa, (1851); Idaho, (1864); Kansas, (1859); Kentucky, (1851); Minnesota, (1851); Missouri, (1849); Montana, (1865); Nebraska, (1855); Nevada, (1860); New Mexico, (1897); New York, (1848); North Carolina, (1868); North Dakota, (1862); Ohio, (1853) : Oklahoma, (1890); Oregon, (1854); South Carolina, (1870); South Dakota, (1862); Utah, (1870); Washington, (1854); Wyoming, (1869); Wisconsin, (1856); Porto Rico, (1904); a total of twenty-eight states and two territories. ${ }^{58}$ In addition the Federal Equity Rules of 1912 largely follow the Codes. ${ }^{59}$

$\approx$ Cook, Statements of Fact in Pleading under the Codes, 21 Col. I. Rev. 442; Sunderland, 14 Mich. I. R. 273, 551.

so To be discussed later in the proposed book.

T Hepburn, op. cit. 88, 89.

ss See Hinton, Cases on Code Pleading (2d Ed.), 1 ; Sunderland, Cases on Code Pleading, 2, 3 ; Hepburn, op. cit. 142; 1 Ponieroy, Equity Jurisprudence (4th Ed.), §§ 282-288; Shipman, Common Law Pleading (3rd Ed. by Ballantine), 2, 3; 19 A. B. A. Rep. 424-432; 54 Alb. I. J. 203; 21 C. J. 24. For a discussion of the practice in Cal., Colo., Conn., Kans., Ky., Mo., Mont., N. M., N. C., N. D., Ohio, Okla., Wis., see 35 N. Y. State Bar Ass'n Rep. 818, 822, 827, 861, 872, 906, 927, 946, 950, 954, 983, 988, 1027.

Infra, p. 537. 
Of the above states Arkansas, Iowa, Kentucky and Oregon still retain a formal distinction between law and equity. The remainder have the blended system. ${ }^{60}$

Florida adinjted the Code in reconstruction days in 1870 . The times were inauspicious and three years later the Code was supplanted by a modified common law system. ${ }^{61}$ This is the only case where code pleading, once adopted, has been repudiated. ${ }^{62}$

It has been customary to classify the non-code states as common law states and "quasi code" or "quasi common law" states. $^{63}$ The distinction is attempted to be made on the basis of nearness of resemblance to the old common law system or to the code system. But nowhere is the old common law system entirely in force; all the states have made some approach to the code principles. In the non-code states in general the formal distinctions between law and equity are maintained although considerably broken down, especially by the presence of statutes allowing "equitable defenses" in actions at law. ${ }^{64}$ Often some distinction between the forms of action is maintained, such as one between tort and contract; but where the forms of action have been most retained, there is some modification of the common law, particularly the abolition of the distinction between trespass and trespass on the case. ${ }^{65}$ The following may be

${ }^{\infty}$ To be discussed in the proposed book.

or Fla. Laws, 1873, p. 15; Mechanics \& Metals Nat. Bank v. Angel, 85 So. 675 ; Atl. Coast Line R. Co. v. State, 74 So. 595.

C Cf. H. H. Ingersoll, 1 Yale L. J. 89, as to early discontent with the code in North Carolina.

* Hepburn, op. cit. 142; Shipman, op. cit. 1-3.

* Hinton, Equitable Defenses, 18 Mich. L. R. 717; Cook, Equitable Defenses, 32 Yale L. J. 645. That the following only are the states having separate chancery courts: New Jersey, Delaware, Vermont (but with the same judges as the common law courts), Alabama, Arkansas, Mississippi, and Tennessee,-see Ingersoll, 21 Yale I. J. 58; cf. 21 C. J. 24; 1 Pomeroy, Equity Jurisprudence (4th Ed.), $\S \S 282-288$. In the other non-code statcs and in the Federal courts, law and equity are administered as distinct systems but in a single court.

os This is true even in Illinois, whose "pleading and practice are not only derived from the common law system, but they are in fact that system, modified, however, by some legislation, which still leaves them the nearest approach to the English law of procedure, as it existed before the passage of the Judicature Acts, now remaining anywhere in the world." $35 \mathrm{~N}$. Y. State Bar Ass'n Rep. 850. See Smith, Ill. Rev. Stat. (1921), Chap. 110, § 36. Some states provide merely for the joining of counts in trespass and case, 
treated as the "quasi common law" states: Massachusetts, Mississippi, Alabama, Maryland, Tennessee, Georgia, Texas, and Michigan. ${ }^{66}$ The following may be treated as common law jurisdictions: Delaware, District of Columbia, Florida, Illinois, Maine, New Hampshire, New Jersey, Rhode Island, Vermont, Virginia, and West Virginia. ${ }^{67}$ Pennsylvania in 1915 adopted a simplified practice act in some respects unique but probably justifying the inclusion of that state in the class of quasi code states. $^{68}$ In New Jersey, where the equity and law courts are entirely distinct, a Practice Act was adopted in 1912 for the law courts, which was an advanced system modelled on the English practice. This likewise has had an important effect on the recent New York revision of the Code. ${ }^{69}$ Louisiana has a practice code following the civil law of that state. ${ }^{70}$

Ala. Code, 1907, § 5329; R. I. G. L., 1923, § 4874. The Illinois statute has been construed to permit simply of a choice between trespass and case; the chosen form must be followed. Shipman, op. cit. 85, note 4.

${ }^{\infty}$ Cf. Hepburn, op. cit. 142-152; Shipman, op. cit. 2, 3; Ingersoll, 21 Yale L. J. 58-71. On Mass., see Rep. Jud. Comm. (Mass. 1921), 104-106; 6 Mass. L. Q. 104-106; on Ga., Md. and Miss., see 35 N. Y. State Bar Ass'n, 844, 885, 902; on Tenn., see 1 Yale L. J. 89; on the Michigan Judicature Act of 1915, see E. R. Sunderland, 14 Mich. I. R. 273, 383, 441, 551. In Georgia there is a considerable approach to code pleading, equitable and legal relief being available in a single civil action. Ga. Civ. Code, 1911, $\$ \S 5406,5407,5508$, 5509, 5514; Dekle $v$. Carter (1923), 156 Ga. 760, 120 S. E. 9. Jury trials may be had in all equity cases. Ibid., $\S 5422 ; 1$ Cook, CASES oN Equiry, 173. In Mississippi under the Constitution (1890), § 147, the Supreme Court cannot reverse any judgment or decree for any error or mistake as to whether the cause was of equity or of common law jurisdiction. Lee $v$. Lee (Miss. 1924), 101 So. 345.

o Hepburn, op. cit.; Shipman, op. cit.; Ingersoll, op. cit.; on the D. C., I11., Me., N. H., R. I., Vt., Va., see 35 N. Y. St. Bar Ass'n Rep. 834, 850, 880, 932, 1006, 1011, 1027; on I11., see 1 Ill. L. Bull. 1; 5 Ill. L. R. 257; on Va., see 17 Va. Law Reg. 668, 797; 2 ibid. (N. S.), 294; J. R. Tucker, Va. State Bar Ass'n Rep. (1892), 85.

Pa. Prac. Act of 1915, Pa. St. 1920, pp. 17181-17204, the last of a long series of steps, D. W. Amram, 64 U. of Pa. I. R. 223; 66 ibid. 195.

$\infty$ N. J. Laws, 1912, p. 377; Hartshorne, 3 VA. LAw REv. 18; Keasbey, 35 N. Y. St. Bar Ass'n Rep. 934; Conboy, 73 Annals Am. Soc. of Pol. \& Soc. Sc. 170; Sheen's New Jersey Practice Act (1916).

70 Hepburn, op. cit. $16 \mathrm{n}, 78-80$. Under the influence of Edward Livingston, probably the first in this country to be affected by the ideas of Bentham, the Louisiana practice became uniqne. The Code of Practice drafted by Livingston was adopted in 1805 . "From it very many of the best portions of the Field Code were adopted." 19 A. B. A. Rep. 427; 54 Alb. L. J. 204. 
While we deal especially with code pleading in this book it would be a mistake to suppose that a study of the procedure of those other states is not instructive to us. Thus Massachusetts seems to have a very workable system, with particularly simple and desirable methods for stating the case, which may serve as a model for code pleaders. ${ }^{71}$ Again many of those states in certain particulars may be more advanced than the code states. Thus Rhode Island was one of the first and is now one of the few states to follow the English system of allowing pleading in the alternative ; ${ }^{72}$ while New Jersey has the most modern system as respects joinder of parties and of causes, and as respects the rule making power in the judges. ${ }^{73}$ It may be - indeed it is to be hoped - that code pleading will lose its distinctive characteristics in a general American system applied in practically all the states. This would undoubtedly correspond rather closely to the present English system. ${ }^{74}$

\section{Federal, Pligading.}

As a result of history and perhaps in part of an unfortunate belief that under the Federal Constitution separate courts of law and equity are necessary, Congress has failed to provide for the amalgamation of the two systems. ${ }^{75}$ Though the district court now sits both as a court of law and as a court of equity, the two jurisdictions are kept entirely distinct. (There is, however, a statute passed in 1915 allowing equitable defenses in actions at law. $)^{76}$ It is provided that "the forms and modes of proceeding in suits of equity and of adniralty and maritime jurisdiction in the district courts shall be according to the principles, rules, and

${ }^{72} 2$ Mass. Rev. Laws, 1921, Chap. 231, § 147; see 32 Yale L. J. 483 ; 35 N. Y. St. Bar Ass'n Rep. 825; Wm. H. Taft, 18 Yale I. J. 28, 31.

: R. I. Rev. St., 1909, Chap. 283, $\S 20$. It has, however, been given a limited application by the courts. See 31 Harv. L. R. 1034.

See note 69, supra; cf. note 13 , supra.

"On uniformity in procedure, see Hepburn, op. cit. 136, 137; 18 A. B. A. Rep. 33 (1895), creating a Committee on Uniformity of Procedure and Comparative Law, and Report thereof, 19 A. B. A. Rep. 411 (1896); 54 Alb. L. J. 198; also current reports of the present A. B. A. Committee on Uniform Judicial Procedure.

${ }^{75}$ See note 83, infra.

is Act Mar. 3, 1915, 38 Stat. at L. 956, U. S. Comp. Stat. $\S 12519 ; 32$ Yale 'L. J. 645, 646; Adams, 10 A. B. A. Journ. 467; Hinton, 18 Mich. L. R. 717. 
usages which belong to courts of equity and of admiralty respectively," and the Supreme Court of the United States is given power to establish rules of practice. ${ }^{77}$ It has exercised this rule making power, and the equity rules have been subject to several revisions. ${ }^{78}$ The last revision, that of 1912 , much simplified the procedure and closely follows the code provisions in many sections, such as those dealing with parties. There is thus established a uniform simplified procedure in equity for the Federal courts throughout the country. ${ }^{79}$

On the law side the situation is not satisfactory. Here Congress by the Conformity Act, originally passed in 1872, has provicled that "the practice, pleadings, and forms and modes of proceeding in civil causes, other than equity and admiralty causes, in the district courts shall conform, as near as may be, to the practice, pleadings, and forns, and proceedings existing at the time in like causes.in the courts of record of the state within which such district courts are held."80 The first difficulty lies in the question when conformity is to be had. - The Federal courts constitute an entirely independent judiciary system, and no conformity is to be had in conflict with positive provisions of Federal legislation; in any event the conformity is only as "near as may be." The second difficulty is that unlike the equity procedure there is not a unified practice for all the Federal courts. The attempt is made to apply all the cliffering rules followed in the various states. Instead of aiding in establishing uniform pleading generally the Federal conformity practice has simply served to emphasize the discord of our procedure. ${ }^{81}$ To remedy this unfortunate situation The American Bar Association has supported a

"U. S. Rev. Stat. § 917, U. S. Comp. Stat. § 1543.

${ }^{78}$ Hopkins, Féderal Equiry Rules (4th Ed.), 37, et seq.

${ }^{10} 226$ U. S. (Appendix) 1, 33 Sup. Ct. XIX, 57 L. Ed. 1633, 198 Fed. XIX, 115 C. C. A. XIX; W. R. Lane, 27 Harv. L. R. $629 ; 29$ ibid. $55 ; 35$ ibid. 276; Bunker, 11 Mich. L. R. 435; Wurts, 22 Yale L. J. 241; Hopkins, op. cit. note 78, supra.

so U. S. Rev. Stat. § 914, U. S. Comp. Stat. 1913, § 1537. This statute does not apply to proceedings in the Circuit Court of Appeals and the United States Supreme Court which are governed by the common law. Camp v. Gress, 250 U. S. 308.

${ }^{81}$ Hepburn, op. cit. 152-172; 3 Foster, Federal Practice (6th Ed.), 1201, ct scq.; 6 A. B. A. Journ. 525; 35 Harv. L. R. 602; 31 Yale L. J. 447; 25 ibid. $221 ; 15$ Mich. L. R. 325. 
bill before Congress, providing for the establishment of a uniform Federal system at law, with rules made by the Supreme Court, a system comparable to the uniform Federal equity system. ${ }^{82}$ It would seem, however, that remedial provisions should go still further and provide for a single blended system of law and equity as in the code states. According to the better view, a constitutional amendment is not necessary to achieve this result. ${ }^{83}$

\section{REvisions OF THE CODE.}

While legislative tinkering with the codes is usual, a general revision of the entire code has been infrequent, except in its birth state, New York. ${ }^{84}$ There the Code was renumbered and reenacted with some changes in 1849, one year after its adoption, and further important amendments were made in 1851 and 1852. Other amendments followed. A commission was appointed in 1870 to revise and consolidate the statutes relating to courts and procedure. The work of this commission resulted in the passage of a Code of Civil Procedure, commonly called the Throop Code in 1876 and 1877, with an addition made in 1880. By inclusion of various substantive laws it came to number in excess of 3400 sections while the original Field Code contained only $391 \mathrm{sec}-$ tions. ${ }^{85}$

For history of the movement and copy of the bill, see Report of the A. B. Committee on Uniform Judicial Procedure, 5 A. B. A. Journ. 468 (1919); ibid. 509 (1920) ; 48 A. B. A. Rep. 343-361 (1923) ; G. E. Osborne, 7 A. B. A. Journ. 251; W. H. Taft, 8 ibid. 34, 601, 604, 607. See also, T. W. Shelton, 7 ibid. 165; 1 VA. LAw Rev. 89; 5 VA. LAw Rev. 111; A. W. Scott, 38 Harv. L. R. 1; 23 Mich. L. R. 154. In 1923 following the suggestion of Taft, C. J., an additional proposal for the creation of a commission to draft amendments to the statutes simplifying the practice at law was submitted to Congress.

${ }^{83}$ See thorough diseussion of the problem by Dean Pound, 36 A. B. A. Rep. 470 (1911) ; 73 Cent. I. J. 204-210 ; cf. Osborne, 7 A. B. A. Journ. 251; Hepburn, op. cit. 162-164.

* Colorado has, however, empowered its Supreme Court to make and change rules of practice and procedure, which "shall supersede any statute in conflict therewith." I. 1913, p. 447, \& 1, Code C. P., 1921, \& 444. The 1921 edition of the Code, however, repeats the old statutes. For criticism of the rules first drafted by the court (in 1914), see E. L. Regenniter, 18 Col. Bar Ass'n Rep. 131 (1915). The rules were then changed. The Bar Association has since recommended a standing Rules Committee of judges and lawyers, 19 Col. Bar Ass'n Rep. 176, 220 (1916) ; 27 ibid. 339 (1924).

\&s As pointed out by the Report of the Joint Legislative Committee on the 
The Throop Code with amendments, additions and repeals continued in effect until 1920. Attempts were made to secure revisions notably by commissions appointed by the legislature in 1895 and again in 1900, both making reports which were not adopted. In 1904 a Board of Statutory Consolidation, consisting of five ahle lawyers, with Judge A. J. Rodenbeck as chairman, was created to consolidate the general statutes of the state and to revise practice in the courts. The Consulidated Laws of I $90 \%$ was the first fruit of their labors. In 1912 the legislature authorized this board to present a detailed plan for the revision of practice. This was reported in 1915, and consisted of a short practice act of 71 sections, and 401 rules of court, thus definitely following the English precedent. The work was ably done and the Report is available for study in connection with future reforms of pleading. 'The legislature created a Joint Legislative Committee on the Simplification of Civil Practice and referred the report to it. This committee reported in 1919, rejecting the niain feature of the Board report - a short act with broad rule making power in the court - and offering a Civil Practice Act which was adopted in 1920 and went into effect October 1, 1921. ${ }^{86}$

This new act is a combination of the old code and the modern English system. It is not a thorough-going adoption of the English system as was the New Jersey Practice Act of 1912. Certain provisions such as those for joinder of parties are taken directly from the English practice. Unfortunately the legislature seems not to have realized the inter-relation of the various subjects. Thus, having liberalized the provisions for joinder of parties, it proceeded to retain the old code provisions for joinder of

Simplification of Civil Practice (N. Y: 1919), 11, the difference is to a considerable extent accounted for by the inclusion in the later code of provisions of substantive law. See also Hepburn, op. cit. 130, 131; Report of Board of Statutory Consolidation (1914), 4.

${ }^{s}$ N. Y. Laws, 1920, Chap. 925, effective originally April 15, 1921, the time being extended by L. 1921, Chap. 199, § 26, to Oct. 1, 1921. For the history of the act, see Report of Joint Legislative Comm. (1919), 5-35; Report of Board of Statutory Consolidation (1915), 3; A. J. Rodenbeck, 44 N. Y. St. Bar Ass'n Rep. (1921), 532, et seq.; Wickersham, 29 Yale I. J. 904; Medina, 21 Col. L. R. 113; Ingram, 7 A. B. A. Journ. 402; Harley, 11 I1l. Law Rev. 37; Gross, 25 Yale L. J. 369. For the report of the commission of 1895, see 52 Alb. I. J. 390, 408; 53 ibid. 6; Hepburn, op. cit. 130-136. 
causes. The two parts of the code must often be applied together, so that we have two utterly inconsistent tendencies. ${ }^{87}$ Again while some rule making power is given the judges, the Act attempts to prescribe the details of practice, contrary to the teachings of experience under the old New York code. The Act is in inany ways an advance over the former code; it has succeeded in materially reducing the bulk of the code, largely by transferring substantive law provisions to the appropriate substantive law sections; and it incorporates many of the most advanced provisions of the English and other systems. ${ }^{8 s}$ But it continues the old policy of legislative control of the details of practice. ${ }^{89}$ The process of amendment has already begun and unfortunately may be expected to continue. ${ }^{90}$

In 1919 the American Judicature Society prepared a model code and rules of civil procedure. This work is also based

${ }^{\text {s7 }} 32$ Yale L. J. 384 ; 137 E. 66th St. ข. Lawrence, 118 Misc. Rep. 486, 194 N. Y. S. 762 .

ss These will be discussed in appropriate places in the proposed book. Among them may be noted the much more liberal provision as to joinder of parties, pleading in the alternative as to parties, abolition of demurrers, and provision for summary judgment on motion-the latter a most important provision developed under the rules. See Rothschild, 23 Col. L. Rev. 618,732 ; McCall, 10 A. B. A. Journ. 22-24; Walters, 44 N. Y. St. Bar Ass'n Rep., 1921, 400-420; note 86, supra.

$\$$ Arguments of the Committee for refusing to adopt the Board's recommendation are given in its Report, 1919, 5, et seq. It felt that the Board planned to give the judges functions they were not properly called upon to perform, that the code should contain a complete system of practice, rather than have the system partly in the code and partly in rules, and that the legislative system would give definiteness. The State Bar Association seems rather consistently to have favored the plan of the Board and the criticism of the Civil Practice Act was very severe. In general see the reports from 1916 on, and especially 44 N. Y. St. Bar Ass'n Rep., 1921, 420, et seq., 441, et scq., 525, et seq., and remarks of Judge Rodenbeck, 532-545. It was admitted by Judge A. T. Clearwater, an advocate of rule-making power in the judges that "Personally, I am satisfied that the majority of the profession in this State are unwilling that the Judges should formulate rules of procedure." 44 ibid. 531. Such a point of view on the part of the members of the bar, while perhaps typical of a conservative profession, is quite at variance with the practically unanimous view of students of the subject generally. See discussion hereinafter, this article.

${ }^{\infty}$ Amendments to the Civil Practice Act have been made by each succeeding Legislature beginning in 1921. Cf. 46 N. Y. St. Bar Ass'n Rep. 123 (1923), that the amendments were not as numerous as expected. 
largely on the English experience and it, as well as the proposed Rodenbeck Code, should be carefully studied by all draftsmen of codes and rules of procedure. ${ }^{01}$

\section{Functions of Pletading.}

Pleading should perform the office only of aiding in the enforcement of substantive legal relations. It should not limit the operation of the general law which defines rights and duties, privileges and powers of individuals, but should aid in the enforcement of such relations. It is a means to an end, not an end in itself - the "handmaid rather than the mistress" of justice. ${ }^{92}$ This would probably be generally admitted. Even so we will prohably favor a strict enforcement of pleading rules if we expect a great deal of it. As we have seen under the common law system much was expected of pleading. The exact issue had to be defined by it. To enforce this result, the rules were insisted on to an extent that, as it now appears, form was exalted over substance, and the means became the end. Under the civil law little is expected of pleading. Consequently, continental jurists need not insist on the enforcement of pleading rules and their pleading decisions are few. The "liberal" pleader cxpects less of pleading than the "strict" pleader. Consequently we need to determine our point of view before we can decide how to approach pleading problems.

Though we are historically committed to the policy of requiring the pleadings to determine the issuc, and still continue to a considerable extent in this position, we are gradually learning to expect less of pleading. The insistence on it seems often not

${ }^{91}$ Bulletin XIV, Rules of Civil Procedure, Am. Jud. Soc., 1919. For the Rodenbeck Code, see Report of Board of Statutory Consolidation, N. Y. (1915), and $c f$. ibid. (1912). There is also available the valuable Report to the Phi Delta Phi Club by its Committee on the Simplification of the Machinery of Justice printed with accompanying papers in 73 Annals Am. Soc. of Pol. \& Soc. Sc. (1917), 1-229. See also, 41 N. Y. St. Bar Ass'n Rep. (1918), 342-429. For Bibliography of Procedural Reform, see Pound, 11 III. L. Rev. 455, 5 Mass. L. Q. 332, 344; 73 Annals Am. Soc. of Pol. \& Soc. Sc. 90-103; also Report of Bd. of Statutory Consolidation (N. Y. 1912), 221227.

2 Per Collins, M. R., in Re Coles, [1907] 1 K. B. 4; $c f$. Roscoe Pound, Some Principles of Procedural Reform, 1910, 4 I11. L. Rev. 388, 402. Dunnett v. Thornton (1900), 73 Conn. 1, 5, 46 At1. 158. 
worth the price. 'The difficulties are accentuated by lack of sufficiently well-trained lawyers among the members of the bar. It takes great skill as well as a thorough knowledge to be a good pleader. Many judges naturally will hesitate to sacrifice the rights of clients because of the pleading mistakes of their attorneys. Moreover popular opinion is likely always to take the side of the clients which may show itself in legislative action as well as in criticism of the judges. We are therefore in a middle position between the common and the civil law. We still expect something of pleading but are more disposed to realize that there are difficulties in the way of complete achievement of its ends. Hence we have our modern so-called liberal attitude towards it. We tend towards the civil law system; we shall probably not reach it for many generations, if at all. Perhaps, however, the future may devise some test of the relative values of the two, so that a definite choice may be possible.

\section{Issue Pleading, Fact Pleading and Notice Pleading.}

For the present we may attempt to state the main purpose of pleading as we now conceive of it. If the common law may be termed issue pleading, since its main purpose was the framing of an issue, code pleading may be referred to as fact pleading in view of the great emphasis placed under the codes 1pon getting the facts stated. ${ }^{93}$ At the present tine there is advocated what is called notice pleading. This is in general a very brief statement designed merely to give notice to the opponent. It has been used apparently with considerable success in the field of intunicipal courts and is now urged for general adoption. ${ }^{94}$

An analysis of the new proposition shows that it differs in the main in the extent of generality of statement permitted. Thus, instead of describing the particulats of an accident, only the time and fact of the accident are referred to. ${ }^{95}$ There is not so much a change in the kind of pleading as a change in emphasis. The common law pleading both set forth facts and gave notice, but

${ }^{23} 32$ Yale L. J. 483.

* Whittier, Notice Pleading, 31 Harv. L. R. 501; 4 I1l. L. Rev. 174, 178, 182; 5 Ill. L. Rev. 257; Pound, 4 Ill. L. Rev. 388, 497; Willis, 5 I1l. L. Q. 17; 8 Cal. L. Rev. 326; Sunderland, 14 Mich. L. R. 551; 8 Mich. L. R. 400; cf. Isaacs, Logic z. Common Sense in Pleading, 16 Mich. L. R. 589.

is Whittier, op. cit. note 94, supra; 32 Yale L. J. 483. 
stressed mainly the framing of the issue; the code produced one or more issues and gave notice, but did this while setting forth the facts. So notice pleading, giving some facts, presents a very broad issue.

It is perhaps doubtful if we are now prepared to go to the complete lengths of hrevity urged by the proponents of notice pleading, except in isolated cases. But without so doing we may properly put the emphasis where they do. This, it seems, is in effect the modern tendency. The aim of pleadings should be therefore to give reasonable notice of the pleader's case to the opponent and to the court. ${ }^{96}$ "The notice to the court is perhaps the inore important. for in general the opponcnt knows enough about the case to relieve us of worry about him. In fact we have spent altogether too much thought over the danger of surprising a defendant. ${ }^{97}$ If his case is prepared at all adequately he will not be surprised. Our solicitude for him will simply result in giving him opportunities to delay the case and harass his opponent. The main purpose of the pleadings should therefore be to give the trial court a proper understanding of the case. If the trial court is adequately informed of the issue by the pleadings, it means that the parties are likewise so informed. It is for the court not the litigants to vindicate pleading rules. ${ }^{98}$

To state such a purpose is not to solve all pleading problerns, but merely to give what should be the end in view. We may then test our solution of the problems by seeing how well they achieve this end. The code purpose of stating the facts did not work. Facts are not such definite and certain things as the codifiers apparently believed. There are more specific facts and less specific facts, but not merely facts as isolated from law or evidence. This was the least successful part of the code reform. ${ }^{99}$ It may therefore properly give place to the purpose of fair notice.

35 A. B. A. Rep. 614, 638, (cited supra, note 5) stating that the other functions of pleading, so far as they should be retained, will be at least as well served as now. Thurman v. Alvey, $233 \mathrm{~S}$. W. 749; Am. Express Co. v. State, 132 Md. 72, 103 Atl. 96; Anderson v. Mollitor, 193 N. W. 851; Kelley v. Armstrong, 132 N. E. 15.

${ }^{\circ}$ Peckham, J., dissenting in DeGraw $v$. Elmore, 50 N. Y. 1.

${ }_{23}$ Pound, 4 Ill. I. Rev. 388, 402.

${ }^{2}$ See note 55, supra. 


\section{Future Pleading Reform.}

The brief survey of pleading made in this article should show that no system of pleading yet devised may be considered final, and that unless pleading rules are subject to constant examination and revaluation, they petrify and become hindrances, not aids, to the administration of justice. Many lawyers are disturbed by the idea that the rules of practice must be changed. There is always a strife for that delusive certainty in the law. Lawyers who have become accustomed to a system think that it achieves such certainty. Unforttnately, however, that hopedfor end is not secured by repeated attempts to define a pleading rule. This is because the law suit is to vindicate rules of substantive law, not rules of pleading, and the latter must always vield to the former. The uncertainty of pleading rules, even though defined and re-defined, will be only too apparent as we proceed with the discussion of the subject. The matter of joinder of parties is perhaps a striking example of the failure of the courts to clarify the subject by continual definition. Moreover, pleading rules naturally tend to become harsh and inflexible. This has been well expressed by Professor Hepburn when he speaks of "the inveterate nature of the incongruity" between procedure and substantive law: - that "the former petrifies" while the latter is growing, and "the conservatism of the lawyer preserves the incongruity." I It is interesting, if somewhat depressing, to observe the gradual development of an involved and technical practice from the piling up of precedents on an originally simple code. ${ }^{2}$ 'The moral seems clear. 'The ministers of justice must be cternally on the job of keeping their tools keen and bright. It is not a mistortune for a code of procedure to require revision; it is its nature.

\section{Rule-Making Power in the Judges.}

How should such revision be accomplished with the least disturbance? A general periodic revision of the code is disturbing; further it is not necessary. If the court is empowered and directed to make and alter rules of practice, the requisite flexibility

1 Hiepburn, Development of Code Pleading, 31.

${ }^{2}$ Compare as to pleading negligence in Connecticut, 32 Yale L. J. 483. 
of procedure may be obtained. Any change made at any one time is likely to be sc small as not to give the effect of constant change and uncertainty in the entire code, and yet some change will actually be expanding and developing the code as need seems to demand. This system has worked well in England and in some states in this country where it is followed in whole or in part. $^{3}$ It is almost universally considered by writers as the first and fundamental step in procedural reform. ${ }^{4}$ Of objections raised to it none seem substantial except the one that the courts too will not exercise the power, a criticism of the courts rather than the system. The objection of resulting uncertainty in the practice has been stated. The objection that this is not a judicial function has been often answered; in fact, according to the view of many, the court has the inherent power to make such rules even in the absence of statute. ${ }^{5}$ The objection that our judges,

${ }^{3}$ For description of the English system, see Rosenbaum, The Rule Making Power, note 42, supra. Procedural rules of court are provided for by statute in at least New Jersey, Colorado, Connecticut, Alabama, Michigan, Virginia, and New York, and the power probably exists to a limited extent at least in practically all the states. See citations, note 4, infra, and cf. Hepburn, op. cit. 195. On the failure of courts to exercise the power when given them, see Sunderland, 22 Mich. L. R. 293; 15 Mich. L. R. 325. On the refusal to adopt the system more fully in New York in the C. P. A., see note 89 , supra.

( Of the many authorities the following are typical. R. Pound, 10 IIl. L. Rev. 163, 4 I11. L. Rev. 388; Wm. H. Taft, 18 Yale L. J. 28, 32, 72 Cent. L. J. 191, and loc. cit. note 82, supra; S. E. Baldwin, Two Centuries Growth of American Law, 313, 317, 35 N. Y. St. Bar Ass'n Rep. 833; C. A. Boston, 61 U. of P. L. R. 1, 7-10; W. B. Perkins, 10 Mich. L. R. 519, 533; T. W. Shelton, 1 VA. LAw Rev. 89, 5 VA. LAw REv. 111, 73 Annals Am. Suc. of Pol. \& Soc. Sc. 168; O. W. McMurray, 7 Cal. L. Rev. 147; A. J. Rodenbeck, 44 N. Y. St. Bar Ass'n Rep. 532; 72 Cent. L. J. 402; J. J. Thompson, 11 I11. L. Rev. 406; E. M. Morgan, 2 Minn. L. R. 81; E. F. Albertsworth, 7 Corn.

L. Q. 310 ; A. W. Scott, 33 Harv. L. R. 236, 38 Harv. L. R. 1; Z. Chafee, 35 Harv. L. R. 673, 712; Hugh E. Willis, 8 Cal. L. Rev. 326, 5 Ill. L. Q. 17; 73 Annals Am. Soc. of Pol. \& Soc. Sc. 68-77; 3 VA. LAw Rev. 18; 31 Yale L. J. 763 ; 35 A. B. A. Rep. 635 ; 34 ibid. 578, 595-600; 10 A. B. A. Journ. 589; Report Board of Statutory Consolidation (N. Y. 1915), 5, 6, 170-177; ibid. (1912) 27-82. For a somewhat contrary view, see A. M. Kales, 4 I11. I. Rev. 303, 324 (1909), 5 ibid. 336 (1911); and compare HEPBURN, DEVELOPMENT of Code Pleading, $\S 224 ;$ N. Y. Joint Committee, cited note 89, supra; H. T. Gilbert, Proc. I1l. Bar Ass'n (1909), 328.

- Among the authorities cited in note 4, supra, see especially Pound, 10 
being politically chosen, are not sufficiently able to regulate practice seems to give its own answer. By all means let us have abler judges, if possible; but no system of arbitrary technical rules, the exact meaning of which is not clear, will make up for lack of ability in the court. That weakness is concealed behind an indelinite rule is no gain. In any event the judges are likely to give better practice rules than the legislature. It is, however, a practical objection that unfortunately the judges too need some stimulus to reform. Perhaps the best method is that of the rulemaking power vested in a unified court, with a directing head, and with some agency, possibly a "ministry of justice," responsible to the electorate and charged with the duty of initiating and advocating reforms of this kind. ${ }^{6}$

\section{An Initial General Revision of the Code.}

Should the entire code be revised, as a preliminary to the establishment of rule-making power in the judges? No totally new system is apparently now to be desired, but nevertheless it seems desirable, as the New York Board of Statutory Consolidation concluded, to repeal the present code entirely. In its place may be substituted a statute committing the entire matter of pleading to the courts under their rule-making power, as in Colorado; or a short general code, giving the fundamental principles of practice, and committing the details to the courts, as in New Jersey and under the system proposed by the Board of Statutory Consolidation for New York." The change will not be as great as the lawyers are likely to fear, for the fundamentals of pleading will remain the same. It will probably be not more than that cccasioned by the Civil Practice Act of 1920 in New York, though the framers of that act refused the more thorough reform on the ground of the drastic character of the change and consequent un-

I11. L. Rev. 163, 170, 177; see also, A. J. Rodenbeck, 41 N. Y. St. Bar Ass'n Rep. 242-256, on New York.

- See a suggestive article by Prof. E. R. Sunderland, Machinery of Procedural Reform, 22 Mich. L. R. 293; McMurray, Procedural Reform, 7 Cal. L. Rev. 147.

T The former is the system preferred by Dean Pound, 10 Ill. L. Rev. 163, 176. 
settlement of practice. Nor should revision mean simply the transfer of the present provisions from the statutes to the rules. Improvement in the statement of the provisions themselves is most desirable. It is only an unsubstantial dream to think that constant attempts at definition have made these provisions clear; they merely served to make the blindness of the provisions more apparent. The original framers of the code desired to lay down rigid rules that would leave nothing to discretion and the operation of which could always be definitely foretold. Even in taking over equity principles of convenience and flexibility, they attempted a precise statement with a seemingly definite eontent, as in the case oi joinder of parties and of actions. This was most unfortunate, as it has turned out in practice. ${ }^{8}$ It does not seem possible to apply mechanical rules to pleading, where the enforcement of such rules is not the end in vieze in the litigation. The terms used by the codifiers proved hopelessly indefinite. The rules may be reframed to indicate the purpose sought to be achieved. They may give the guiding principle to the court, but this inust be worked out by the court itself, and a large measure of discretion is necessary. Thus, under the English, New Jersey and New York acts the guiding principle of joinder of parties is made to be the "existence of a common question of law and fact." This seems a much more workable principle than the blind language of the old code. ${ }^{\circ}$ Further improvement along this line seems possible.

\section{Incidental Reforms in Pleading.}

As hereinafter indicated, a clearer analysis of many pleading problems may aid to better the practice. But there are several instances where the codes or governing rules themselves should be amended to permit of desirable changes. These proposed amendments also are discussed in their appropriate connections in the following pages. Among these may be included freer joinder of parties plaintiff and defendant, and of causes of action, including freer privileges of bringing in new parties and of

Clark, The Code Cause of Action, 33 Yale L. J. 817. Cf. S. H. Allen, 10 A. B. A. Journ. 115; R. Pound, The Decadence of Equity, 5 Col. L. Rev. 20 ; R. Pound, 10 Ill. L. Rev. 163, 167.

Ibid. 
intervention; the waiver of jury trial by failing to claim it within the proper time; pleading in the alternative both as to parties and as to the facts; restriction of the relief granted to that claimed only in cases of non-appearance (not where no answer is filed); abolishment of the demurrer and the taking of objection by motion; summary judgment on motion; still freer power of amendment; the declaratory judgment, etc. ${ }^{10}$

\section{Miscellaneous Practice Reforms.}

These changes in the rules of pleading should be accompanied by changes in the organization of the courts and in other parts of the practice system. It seems that the jurges will not exercise their rule-making function without some directing head, and perhaps not even then without impetus given by some social agency in touch with and responsive to political needs. ${ }^{11}$ Thus the systen 1 so generally urged to secure administrative efficiency in the courts of a unified court of many judges under the direction of a presiding judge appears also necessary in connection with the suggested pleading reforms. ${ }^{12}$ Along with this may go the

${ }^{10}$ The reasons for these changes are stated in the discussion in the book as to each one. Many were included in the code of the Board of Statutory Consolidation, N. Y. 1915, and are among those stated by the Joint Legislative Committee on the Simplification of Civil Practice (N. Y. 1919), 27 to have met "with a most uniform general disapproval" from the profession in New York. "The number of lawyers who responded to that important communication [the Committee's questionnaire] was so negligible as hardly worth reciting in numerals." A. T. Clearwater, 43 N. Y. St. Bar Ass'n Rep. 145.) It is recognized that reform measures should not be obnoxious to the lawyers, for it is the bench and bar who must work with the rules of practice and pleading. Nevertheless it seems always true that many, perhaps most of the bar, will prefer the system with which they are familiar, rather than something unknown which may even work better. Practice reforms from the days of Jeremy Bentham and of David Dudley Field have always had to meet such opposition. See note 27, supra; Hepburn, op. cit. 18 . It seems, therefore, that a change otherwise desirable ought not to be refused merely beeause of such opposition. In time it will probably change to support as in the case of the code generally.

${ }^{11} C f$. Sunderland and McMurray, op. cit. note 5, supra.

12 Harley, Business Management for the Courts, 5 VA. LAW REv. 1; 25 Yale L. J. 443; Thompson, The Machinery of Justrce, 11 Ill. L. Rev. 406; Sims, 3 VA. Law Rev. 598; Pound, 4 Ill. I. Rev. 388; Report of Phi Delta Phi Committee, and papers by Jessup, Harley, Wells, Alger and others, 73 Annals Am. Soc. of Pol. \& Soc. Sc. (1917), 1, et seq.; 10 A. B. A. Journ. 
"ministry of justice" the function of which shall be to provide the initial urge for inprovement. ${ }^{13}$. So there should be provided masters or court officers to frame issues for the parties when these are not made clear by the parties thenselves. ${ }^{14}$ At the same time other fields of practice deserve careful study. Thus calendar practice - the method of assigning cases ready for trial is usually wastéful and inefficient. In particular the practice of appellate review requires revision. Simplification of the making up of the record, provision for the taking of evidence on appeal; for amendment before the appellate court, and for the liniting of an orcler for a new trial to the question of damages only are among the reforms urgently needed. ${ }^{15}$

\section{Abolition of Pleadings.}

All pleadings have been dispensed with before some tribunals, notably adninistrative tribunals such as workmen's compensation and public utilities commissions, special courts such as probate courts, and courts for the expeditious settlement of small claims. It has been feared by some lawyers that this was the forerunner of a general movement to abolish all pleadings. ${ }^{16}$ It would seem, however, that these cases are of a special nature. In the case of small claims courts, the matter in dispute is small and usually there is little issue to be made, the defendant's real hope of dcfense being the expense to the plaintiff. Here formal pleadings should be dispensed with to save delay and expense. ${ }^{17}$

105; 34 A. B. A. Rep. 589; Bulletin VIIA, State Wide Judicature Act, Am. Jud. Soc. (1917), and current numbers of Journ. of Am. Jud. Soc.

${ }^{23}$ Cardozo, A Ministry of Justice, 35 Harv. L. R. 113; Sunderland, op. cit. note 5 , supra.

14 See note $13, \cdot$ supra.

15 See Albertsworth, Leading Developments in Procedural Reform, 7 Corn. L. Q. 310; Pound, 4 Ill. L. Rev. 388, 491 ; Osborne, 7 A. B. A. Journ. 245; 71 U. of Pa. L. R. 79; Tinker v. Sauer, 106 Ohio St. 135; 32 Yale L. J. 506; Robinson $v$. Payne (N. J.), 122 Atl. 882; 33 Yale L. J. 886.

${ }^{16}$ On the movement to abolish all pleadings, see Rosenbaum, THE Rule Making Authority, 73, 80; Thayer, Prelim. Treatise, $367, \mathrm{n} .3$. On the growth of administrative justice, see Pound, LAw AND Morals (1924), 59; Pound, Justice According to Law-Executive Justice, 14 Col. L. Rev. 12; Pound, 44 A. B. A. Rep. 445 (1919); Smith, Administrative Justice, 18 Ill. I. Rev. 211; W. D. Guthrie, 46 N. Y. St. Bar Ass'n Rep. 169, 175.

${ }^{17}$ Smith, Justice and The Poor, 41, 52, 54, 56. 
In the other cases, the issues in each case are usually defined by the statute or governing rule and are substantially the same for every case. ${ }^{18}$ Where the question is defined by the nature of the proceeding and does not depend upon the circumstances of the particular case, formal pleadings are not necessary. In England in certain actions to recover a clebt or liquidated demand the plaintiff may make his Statement of Claim, in short form by special endorsement on his writ of summons. Again, the parties by agreeing on the issues may dispense with pleadings. ${ }^{19}$ Beyond cases of these types it is not probable that the abolition of pleadings will go at the present time. ${ }^{20}$

\section{Development of Procedural Jurisprudence.}

It has already been noted that unlike the continental countries, there has been little attempt in our system of law to develop a procedural jurispruclence. ${ }^{21}$ All our attention has been directed to the immediately practical and almost no attempt has been made to state fundamentals. In fact high authorities have urged that it was impossible to study pleading as a general science: all that should be atternptcd was the local code. ${ }^{22}$ One result of that is seen in the lack of knowledge and even the aversion to knowledge of advances in pleading made in other jurisdictions shown by the average lawyer. It is believed that the hope for real pleading reforms and for the developing of a uniform system of procedure rests. largely upon the development of a different attitude towards the study of pleading - an attitude that it is not so much local

${ }^{18}$ E. g., the question whether a will is entitled to probate, the question whether an accident "arose out of and in the course of the employment" of a workman, the question whether a claimant was dependant upon a workman, etc.

19 Ann. Prac., 1924, p. 13, O. 3, r. 6 ; ibid., p. 560, O. 34, r. 9. Cf. Ackerman \& Hartnick, Inc. v. Berkowitz (1924), 206 N. Y. S. 624.

${ }^{\infty}$ From Nov. 1893 to Feb. 1917 in England power was given to a plaintiff to dispense with pleadings but the experiment proved a failure and Order XVIIIA was annulled at the latter time. See Odgers, Pleading and PracTICE (8th Ed.), 43.

${ }^{21}$ See note 17 , supra, citing Millar, The Formative Principles of JuRISPRUDENCE.

22 C. W. Pound, Handbook of the Ass'n of Am. Laiv Schools (1922), 99, 106; (1919), 4 Corn. L. Q. 143; C. M. Hough, Hannoook Ass'N Am. LAW ScHOOLS (1922), 110, 112. 
"practical" subject, as a general "theoretical" one. ${ }^{23}$ Happily there are many signs of the broader conception. ${ }^{24}$

Charles E. Clark.

\section{YALE LAW SchooL.}

${ }^{3}$ Cf. 33 Yale L. J. 109; E. R. Sunderland, 36 Harv. L. R. 239; J. B. Winslow, Relation of Legal Education to Simplicity in Procedure (1912), 37 A. B. A. Rep. 741.

2s See the work of Professor Millar noted above, note 19, supra, and compare the interest in the subject shown by the Association of American Law Schools, McBaine, Handbook Ass'N Am. Law Schools (1922), 112, replying to Judges Pound and Hough, note 22, supra; Sunderland (1922), ibid. 169, 21 Mich. L. R. 372, 29. W. Va. L. Q. 77; McCaskill (1924), 5 Am. L. Sch. Rev. 286; Scott, 7 A. B. A. Journ. 315; Osborne, 7 A. B. A. Journ. 245. Thus, the comparative study of declaratory judgment ( $c f$. Borchard, 27 Yale L. J. 1 ; Sunderland, 16 Mich. L. R. 69) has been of important service in the development of that reform. For Bibliography of Procedural Reform, see note 91 , supra. 